\title{
Effect of Zinc, Boron and Iron on Growth and Phenological Characters of Brinjal (Solanum melongena L.)
}

\author{
S. Uikey ${ }^{1}$, M.P. Das ${ }^{1 *}$, P. Ramgiry ${ }^{1}$, D. Vijayvergiya ${ }^{1}$, P. Ghaday ${ }^{1}$, \\ S.A. Ali ${ }^{1}$ and J. Pradhan ${ }^{2}$ \\ ${ }^{1}$ Department of Horticulture, R.A.K College of Agriculture, Rajmata Vijayaraje Scindia Krishi \\ Vishwa Vidyalaya, Sehore-466001 (M.P), India \\ ${ }^{2}$ Department of Agricultural Meteorology, College of Agriculture, Orissa University of \\ Agriculture and Technology, Bhubaneswar, India \\ *Corresponding author
}

\begin{abstract}
A B S T R A C T
An experiment was conducted to find out the suitable micronutrient or their combinations for foliar sprays in brinjal at the Horticulture Research Farm, R.A.K College of

Keywords

Micronutrients, Eggplant, Zinc, Iron, Borax

Article Info

Accepted: 10 August 2018 Available Online: 10 September 2018 Agriculture, Sehore (M.P). The experiment comprised of total eight treatments micronutrients and control. The experiment was laid out in randomized completely block design with three replications. Application of RDF and foliar spray of micronutrients treatment $\mathrm{T}_{8}\left(\mathrm{RDF}+\right.$ Borax $(0.2 \%)+\mathrm{FeSO}_{4}(0.5 \%)+\mathrm{ZnSO}_{4}(0.5 \%)$ recorded significantly growth (viz., plant height, number of leaves plant ${ }^{-1}$, number of branches plant ${ }^{-1}$, leaf area plant $^{-1}$ and leaf area index) and phonological parameters (i.e. earliest first flowering, first fruit set and first picking and highest number of flowers cluster ${ }^{-1}$ and number of fruits cluster $\left.^{-1}\right)$. All the growth and phenological attributes of brinjal viz., plant height (82.67 $\mathrm{cm})$, no. of leaves (173.27), no of branches (12.60), leaf area $\left(2431.12 \mathrm{~cm}^{2}\right)$, leaf area index (0.540), and days to $1^{\text {st }}$ flower initiation (37.33), days to first fruit set (42.33), days to $1^{\text {st }}$ picking (58.33), number of clusters/plant (3.6), no. of flowers per cluster (5.2), number of fruits/ cluster (3.3) were recorded best in treatment $\mathrm{T}_{8}\left(\mathrm{RDF}+\right.$ Borax $(0.2 \%)+\mathrm{FeSO}_{4}$ $(0.5 \%)+\mathrm{ZnSO}_{4}(0.5 \%)$.
\end{abstract}

\section{Introduction}

Brinjal (Solanum melongena L.), or eggplant is one of the most common, popular and principle vegetable crop grown in India and other parts of the world. The brinjal is of much important in the warm areas of Far East, being grown extensively in India and other Asian countries like Bangladesh, Pakistan, and Philippines. Other major brinjal producing countries are China, Turkey, Japan, Egypt, Indonesia, Iraq, Italy, Syria and Spain. India contributes 13.44 million tonnes to the global production of brinjal in 2014-2015 and ranks second to China (NHB, at a galance 2015).

Brinjal occupies third position amongst vegetable crops grown in India, it covers i.e. 680.0 thousand hectare with a productivity of $18.70 \mathrm{t} \mathrm{ha}^{-1}$ and produces 12706.0 thousand tonnes in India in 2014-2015. Analysis of soil 
and plant samples has indicated that $49 \%$ soils in India are potentially deficient in $\mathrm{Zn}, 12 \%$ $\mathrm{Fe}, 5 \% \mathrm{Mn}, 3 \% \mathrm{Cu}, 33 \% \mathrm{~B}$ and $11 \%$ in $\mathrm{Mo}$. Basal application to soil and or foliar sprays of $\mathrm{Zn}, \mathrm{B}$ and Mo and foliar sprays of Fe and $\mathrm{Mn}$ have been recommended as the most suitable methods for correcting such deficiencies in crops (Singh 2008). Extent of micronutrients deficiency in NFSM States- (in M.P. sample deficient $\mathrm{Zn} 44 \%, \mathrm{Cu}<1 \%, \mathrm{Fe}>1 \%$, Mn $1 \%$, B 22\%, Mo 18\%). Application of micronutrients along with judicious use of nutrients (at RDF) will not only enhance productivity but will also increase the total production and the efficiency of fertilizer use in brinjal crop. While doing so, there is an urgent need to augment supplies of customized fertilizers supplying secondary and micronutrient to support sufficiently, the integrated use of nutrient management in brinjal production

\section{Materials and Methods}

The experiment was conducted at the Horticulture Research Farm, R.A.K College of Agriculture, Sehore (M.P) during kharif season of 2016-17. The land topography of the experimental site was almost uniform with an adequate surface drainage. The experiment was laid out in randomized completely block Design with three replications and eight treatments (Table 1).

Details of treatments used in the study

$\mathrm{T}_{1}$-RDF (100:60:50 kg NPK/ ha) as control

$\mathrm{T}_{2}-\mathrm{RDF}+$ Borax $0.2 \%$

$\mathrm{T}_{3}-\mathrm{RDF}+\mathrm{FeSO}_{4} 0.5 \%$

$\mathrm{T}_{4}-\mathrm{RDF}+\mathrm{ZnSO}_{4} 0.5 \%$

$\mathrm{T}_{5}-\mathrm{RDF}+$ Borax $(0.2 \%)+\mathrm{FeSO}_{4}(0.5 \%)$

$\mathrm{T}_{6}-\mathrm{RDF}+\operatorname{Borax}(0.2 \%)+\mathrm{ZnSO}_{4}(0.5 \%)$
$\mathrm{T}_{7}-\mathrm{RDF}+\mathrm{FeSO}_{4}(0.5 \%)+\mathrm{ZnSO}_{4}(0.5 \%)$

$\mathrm{T}_{8}-\mathrm{RDF}+\operatorname{Borax}(0.2 \%)+\mathrm{FeSO}_{4}(0.5 \%)+$ $\mathrm{ZnSO}_{4}(0.5 \%)$

30 days old seedlings of brinjal (cv. UTKARSHA-F $\mathrm{F}_{1}$ hybrid Ankur) with a spacing of $75 \mathrm{~cm}$ row to row and $60 \mathrm{~cm}$ plant to plant transplanted in the plots in the afternoon hours immediately followed by irrigation for proper establishment of the seedlings.Observations were recorded on growth and phenological parameters. The data so generated was statistically analysed.

\section{Results and Discussion}

Effect of different treatments of foliar sprays of micronutrients on growth parameters of brinjal

The data presented in Table 1 demonstrates that the foliar application of micronutrients significantly influenced the growth parameters of brinjal plants. It clearly shows that the combine foliar sprays of micronutrients (zinc, boron and iron) caused an increase in height of the eggplant but in control treatments without foliar application of micronutrient shows decreased in plant height. The maximum plant height of eggplant $(82.67 \mathrm{~cm})$ was found in treatment $\mathrm{T}_{8}\left(\mathrm{RDF}+\right.$ Borax $(0.2 \%)+\mathrm{FeSO}_{4}$ $(0.5 \%)+\mathrm{ZnSO}_{4}(0.5 \%)$ followed by $\mathrm{T}_{6}$ $\left(\mathrm{RDF}+\right.$ Borax $(0.2 \%)+\mathrm{ZnSO}_{4}(0.5 \%)(60.86$ $\mathrm{cm})$ at 120 days after transplanting. However, minimum plant height $(63.68 \mathrm{~cm})$ was observed in treatment $T_{1}(R D F$ 100:60:50 kg NPK/ ha) as control. The increase in plant height may be due to application of major and minor nutrients, through foliar sprays of different micronutrients, increased the photosynthetic activity, chlorophyll formation, nitrogen metabolism and auxin contents in the plants which ultimately improving the plant height. The findings is also in agreement with 
the findings of Naga et al., (2013), Mohsen (2013), Singh et al., (2014), Gogoi et al., (2014), Kadari, et al., (2015), Meena et al., (2015), Samira et al., (2015), and Pandav et al., (2016).

The treatments $\mathrm{T}_{8}(\mathrm{RDF}+$ Borax $(0.2 \%)+$ $\mathrm{FeSO}_{4}(0.5 \%)+\mathrm{ZnSO}_{4}(0.5 \%)$ was recorded maximum number of leaves plant ${ }^{-1}$ followed by $\mathrm{T}_{6}\left(\mathrm{RDF}+\operatorname{Borax}(0.2 \%)+\mathrm{ZnSO}_{4}(0.5 \%)\right.$ and $\mathrm{T}_{5}\left(\mathrm{RDF}+\right.$ Borax $(0.2 \%)+\mathrm{FeSO}_{4}(0.5 \%)$ and treatment $\mathrm{T}_{8}$ and $\mathrm{T}_{6}$ were at par with each other at 120 DAT. However, minimum number of leaves/plant was observed in treatment $T_{1}$ (RDF 100:60:50 kg NPK/ ha) as control.

Foliar sprays of Zinc, Iron and Boron increased the nitrogen content of the leaves. Number of leaves increased may be due to promotive effects of macro and micronutrients on vegetative growth which ultimately lead to more photosynthetic activities. Similar results have been reported by Kiran et al., (2010), Ali et al., (2013), Singh et al., (2014), Gogoi et al., (2014), Tawab et al., (2015) and Samira et al., (2015).

The number of branches/plant of brinjal increased significantly with the increased crop growth period. Treatments $\mathrm{T}_{8}(\mathrm{RDF}+$ Borax $(0.2 \%)+\mathrm{FeSO}_{4}(0.5 \%)+\mathrm{ZnSO}_{4}(0.5 \%)$ was recorded maximum number of branches/plant followed by $\mathrm{T}_{6}\left(\mathrm{RDF}+\right.$ Borax $(0.2 \%)+\mathrm{ZnSO}_{4}$ $(0.5 \%)$ and $\mathrm{T}_{5}\left(\mathrm{RDF}+\operatorname{Borax}(0.2 \%)+\mathrm{FeSO}_{4}\right.$ $(0.5 \%)$ and treatment $\mathrm{T}_{8}$ and $\mathrm{T}_{6}$ were at par with each other at 120 DAT. However, minimum number of branches/plant was observed in treatment $T_{1}$ (RDF 100:60:50 kg NPK/ ha) as control. Probable reason for increased number of branches due to the increased rates of photosynthesis and photosynthates supply for maximum branches growth or change in endogenous auxin in turn in apical dominance. These findings are in agreement with the findings of Natesh et al., (2005), Kiran et al., (2010), Savitha et al.,
(2010), Dubey et al., (2013), Naga et al., (2013), Mohsen (2013), Singh et al., (2014), Gogoi et al., (2014) and Meena et al., (2015).

Similarly maximum leaf area/plant was exhibited in $\mathrm{T}_{8}\left(\mathrm{RDF}+\right.$ Borax $(0.2 \%)+\mathrm{FeSo}_{4}$ $(0.5 \%)+\mathrm{ZnSO}_{4}(0.5 \%)$ followed by $\mathrm{T}_{6}$ $\left(\mathrm{RDF}+\operatorname{Borax}(0.2 \%)+\mathrm{ZnSO}_{4}(0.5 \%)\right.$.

Leaf area was significantly increased by nitrogen, possibly because nitrogen helps in greater assimilation of food material by the plant which resulted in greater meristematic activities of cells and consequently the number of leaves, length and width of leaf of plant. These findings are in agreement with the results reported by Das et al., (1978) and Yadav et al., (2001).

The leaf area index increased significantly with the increased crop growth period. Significantly maximum leaf area index was estimated in $\mathrm{T}_{8}\left(\mathrm{RDF}+\right.$ Borax $(0.2 \%)+\mathrm{FeSO}_{4}$ $(0.5 \%)+\mathrm{ZnSO}_{4}(0.5 \%)$ followed by $\mathrm{T}_{6}$ $\left(\mathrm{RDF}+\right.$ Borax $(0.2 \%)+\mathrm{ZnSO}_{4}(0.5 \%)$ as compared to rest of the treatment, while, the minimum leaf area index was observed in treatment $\mathrm{T}_{1}$ (RDF 100:60:50 kg NPK/ ha) as control. Leaf area index was significantly increased by nitrogen, possibly because nitrogen helps in greater assimilation of food material by the plant which resulted in greater meristematic activities of cells and consequently the number of leaves, length and width of leaf of plant.

\section{Effect of different treatments of foliar sprays of micronutrients on phenological parameters of brinjal}

Among phenological parameters, the days to first flower initiation, days to first fruit set, days to first picking, number of flowers/cluster, number of fruits/cluster and number of cluster/plant were studies in brinjal (Table 2). 
Table.1 Effect of micronutrients on plant height $(\mathrm{cm})$, No of leaves/plant, No of branches/plant, Leaf area $\left(\mathrm{cm}^{2}\right)$, Leaf area index of brinjal cv UTKARSHA-F $\mathrm{F}_{1}$ hybrid Ankur

\begin{tabular}{|c|c|c|c|c|c|}
\hline Treatment & $\begin{array}{c}\text { Plant } \\
\text { height(cm) }\end{array}$ & $\begin{array}{c}\text { No of } \\
\text { leaves/plant }\end{array}$ & $\begin{array}{c}\text { No of } \\
\text { branches/plant }\end{array}$ & $\begin{array}{l}\text { Leaf area } \\
\quad\left(\mathrm{cm}^{2}\right)\end{array}$ & $\begin{array}{l}\text { Leaf area } \\
\text { index }\end{array}$ \\
\hline $\begin{array}{l}\mathrm{T}_{1}=\mathrm{RDF}(100: 60: 50 \mathrm{~kg} \mathrm{NPK} / \\
\text { ha) control }\end{array}$ & 63.68 & 144.07 & 7.40 & 1826.37 & 0.406 \\
\hline $\mathrm{T}_{2}=\mathrm{RDF}+\operatorname{Borax} 0.2 \%$ & 72.29 & 162.33 & 10.00 & 2112.63 & 0.470 \\
\hline $\mathrm{T} 3=\mathrm{RDF}+\mathrm{FeSO}_{4} \mathbf{0 . 5 \%}$ & 69.25 & 149.07 & 8.70 & 1921.93 & 0.427 \\
\hline $\mathrm{T}_{4}=\mathrm{RDF}+\mathrm{ZnSo}_{4} \mathbf{0 . 5 \%}$ & 70.76 & 156.87 & 9.30 & 1994.47 & 0.443 \\
\hline $\begin{array}{l}\mathrm{T}_{5}=\mathrm{RDF}+\mathrm{Borax}(0.2 \%)+ \\
\mathrm{FeSO}_{4}(0.5 \%)\end{array}$ & 74.11 & 166.20 & 11.33 & 2294.12 & 0.510 \\
\hline $\begin{array}{l}\mathrm{T}_{6}=\mathrm{RDF}+\text { Borax }(0.2 \%)+ \\
\mathrm{ZnSo}_{4}(0.5 \%)\end{array}$ & 80.61 & 170.80 & 12.20 & 2393.71 & 0.532 \\
\hline $\begin{array}{l}\mathrm{T}_{7}=\mathrm{RDF}+\mathrm{FeSo}_{4}(0.5 \%)+ \\
\mathrm{ZnSo}_{4}(0.5 \%)\end{array}$ & 72.04 & 159.53 & 9.67 & 2010.86 & 0.469 \\
\hline $\begin{array}{l}\mathrm{T}_{8}=\mathrm{RDF}+\mathrm{Borax}(0.2 \%)+ \\
\mathrm{FeSO}_{4}(0.5 \%)+\mathrm{ZnSO}_{4}(0.5 \%)\end{array}$ & 82.67 & 173.27 & 12.60 & 2431.12 & 0.540 \\
\hline S.Em \pm & 0.51 & 2.82 & 0.59 & 33.13 & 0.007 \\
\hline C.D.5\% level & 1.55 & 8.56 & 1.79 & 100.51 & 0.022 \\
\hline
\end{tabular}

Table.2 Effect of micronutrients on Days to $1^{\text {st }}$ flower initiation, Days to first fruit set, Days to $1^{\text {st }}$ picking, Number of clusters/plant, No. of flowers per cluster and Number of fruits/ cluster of brinjal cv UTKARSHA-F ${ }_{1}$ hybrid Ankur

\begin{tabular}{|c|c|c|c|c|c|c|}
\hline Treatment & $\begin{array}{l}\text { Days to } 1^{\text {st }} \\
\text { flower } \\
\text { initiation }\end{array}$ & $\begin{array}{l}\text { Days to first } \\
\text { fruit set }\end{array}$ & $\begin{array}{l}\text { Days to } 1^{\text {st }} \\
\text { picking }\end{array}$ & $\begin{array}{c}\text { Number of } \\
\text { clusters/plant }\end{array}$ & $\begin{array}{c}\text { No. of } \\
\text { flowers } \\
\text { per cluster }\end{array}$ & $\begin{array}{l}\text { Number } \\
\text { of fruits/ } \\
\text { cluster }\end{array}$ \\
\hline $\begin{array}{l}T_{1}=\text { RDF } \quad(100: 60: 50 \mathrm{~kg} \\
\text { NPK/ ha }) \text { control }\end{array}$ & 41.67 & 47.67 & 64.33 & 5.3 & 3.2 & 2.1 \\
\hline $\mathrm{T}_{2}=\mathrm{RDF}+$ Borax $0.2 \%$ & 39.33 & 45.00 & 61.00 & 4.5 & 4.4 & 2.7 \\
\hline $\mathrm{T} 3=\mathrm{RDF}+\mathrm{FeSO}_{4} 0.5 \%$ & 41.00 & 47.00 & 63.33 & 4.6 & 3.7 & 2.4 \\
\hline $\mathrm{T}_{4}=\mathrm{RDF}+\mathrm{ZnSO}_{4} 0.5 \%$ & 40.67 & 46.67 & 62.67 & 4.4 & 3.8 & 2.5 \\
\hline $\begin{array}{l}\mathrm{T}_{5}=\mathrm{RDF}+\text { Borax }(0.2 \%) \\
+\mathrm{FeSO}_{4}(0.5 \%) \\
\end{array}$ & 39.00 & 44.33 & 60.33 & 4.4 & 4.6 & 2.7 \\
\hline $\begin{array}{l}\mathrm{T}_{6}=\mathrm{RDF}+\text { Borax } \\
+\mathrm{ZnSO}_{4}(0.5 \%) \\
\end{array}$ & 38.00 & 43.00 & 59.00 & 4.1 & 4.8 & 2.9 \\
\hline $\begin{array}{l}\mathrm{T}_{7}=\mathrm{RDF}+\mathrm{FeSO}_{4}(0.5 \%) \\
+\mathrm{ZnSo}_{4}(0.5 \%)\end{array}$ & 40.00 & 45.67 & 61.67 & 4.3 & 4.0 & 2.7 \\
\hline $\begin{array}{l}\mathrm{T}_{8}=\mathrm{RDF}+\text { Borax }(0.2 \%) \\
+\mathrm{FeSO}_{4}(0.5 \%)+\mathrm{ZnSO}_{4} \\
(0.5 \%)\end{array}$ & 37.33 & 42.33 & 58.33 & 3.6 & 5.2 & 3.3 \\
\hline S.Em \pm & 0.26 & 0.38 & 0.35 & 0.23 & 0.23 & 0.17 \\
\hline C.D.5\% level & 0.79 & 1.17 & 1.08 & 0.70 & 0.72 & 0.51 \\
\hline
\end{tabular}


The earliest first flowering was recorded under treatment $\mathrm{T}_{8}(\mathrm{RDF}+\operatorname{Borax}(0.2 \%)+$ $\mathrm{FeSO}_{4}(0.5 \%)+\mathrm{ZnSO}_{4}(0.5 \%)$ as compared to other treatment the and late flowering was noted in treatment $\mathrm{T}_{1}$ (RDF 100:60:50 kg NPK/ ha) as control. B showed the highest P and $\mathrm{K}$ uptake at the pre flowering $(\mathrm{P} \& \mathrm{~K})$ and flowering ( $\mathrm{P}$ only) stages. This was attributed to the increased photosynthesis and effective translocation of photosynthates. The findings are in agreement with findings of Naidu et al., (2002), Khedr et al., (2004), Dubey et al., (2013), Ali et al., (2013), and Meena et al., (2015).

The days to first fruit set was significantly influenced due to various treatments of micronutrients. The earliest first fruit set was recorded under treatment $\mathrm{T}_{8}(\mathrm{RDF}+$ Borax $(0.2 \%)+\mathrm{FeSO}_{4}(0.5 \%)+\mathrm{ZnSO}_{4}(0.5 \%)$, followed by $\mathrm{T}_{6}\left(\mathrm{RDF}+\right.$ Borax $(0.2 \%)+\mathrm{ZnSO}_{4}$ $(0.5 \%)$. This might be due to the role of boron in flower development pollen germination fertilization and fruit abscission. Foliar spray of borax at 60 and 90 DAT closely synchronized with fruit development as it plays role in translocation of carbohydrates to developing fruits (Das, 2007). These findings are in agreement with the results reported by Khedr et al., (2004), Natesh et al., (2005), Ali et al., (2013) and Suganiya and Kumuthini. (2015).

The early first picking were recorded in $\mathrm{T}_{8}$ $\left(\mathrm{RDF}+\right.$ Borax $(0.2 \%)+\mathrm{FeSO}_{4}(0.5 \%)+$ $\mathrm{ZnSO}_{4}(0.5 \%)$. Foliar spray of borax at 60 and 90 DAT closely synchronized with fruit development as it plays role in translocation of carbohydrates to developing fruits, the findings are in agreement with the findings of Dubey et al., (2013).

The number of flowers/cluster was significantly influenced due to various treatments. Significantly highest number of flowers/cluster was recorded in treatment $T_{8}$
$\left(\mathrm{RDF}+\right.$ Borax $(0.2 \%)+\mathrm{FeSO}_{4}(0.5 \%)+$ $\mathrm{ZnSO}_{4}(0.5 \%)$. Similarly highest number of fruits/cluster was recorded in treatment $\mathrm{T}_{8}$ $\left(\mathrm{RDF}+\right.$ Borax $(0.2 \%)+\mathrm{FeSO}_{4}(0.5 \%)+$ $\mathrm{ZnSO}_{4}(0.5 \%)$. Whereas highest number of cluster/plant was recorded in treatment $T_{1}$ (RDF 100:60:50 kg NPK/ ha) as control and lowest cluster/plant as observed under the treatment $\mathrm{T}_{8}\left(\mathrm{RDF}+\right.$ Borax $(0.2 \%)+\mathrm{FeSO}_{4}$ $(0.5 \%)+\mathrm{ZnSO}_{4}(0.5 \%)$.Increased number of flower per cluster, number of flowers/cluster, number of fruits/cluster due to foliar spray of micronutrients might be attributed to enhanced photosynthetic activity, resulting in increased production and accumulation of carbohydrates and favorable effect on vegetative growth and flowers, which might have increased number of flower cluster ${ }^{-1}$. These findings are in agreement with the results reported by Ali et al., (2013), Mohsen (2013), Suganiya and Kumuthini. (2015) and Meena et al., (2015).

On the basis of results of present investigation it is concluded that foliar application of micronutrients enhanced most of the growth and phenological attributes of eggplant $\mathrm{cv}$. UTKARSHA-F $F_{1}$ hybrid Ankur. Application of RDF and foliar spray of micronutrients treatment $\mathrm{T}_{8}\left(\mathrm{RDF}+\right.$ Borax $(0.2 \%)+\mathrm{FeSO}_{4}$ $(0.5 \%)+\mathrm{ZnSO}_{4}(0.5 \%)$ were recorded significantly higher growth (viz., plant height, number of leaves plant ${ }^{-1}$, number of branches plant $^{-1}$, leaf area plant ${ }^{-1}$ and leaf area index) and phonological parameters (i.e. earliest first flowering, first fruit set and first picking and highest number of flowers cluster $^{-1}$ and number of fruits cluster ${ }^{-1}$ ).

\section{References}

Ali, Sajid, Javed, Hafiz Umer, Rehman, Rana Naveed Ur, Sabir, Irfan Ali, Naeem, Muhammad Salman, Siddiqui, Muhammad Zeshan, Saeed, Dawood Anser and Nawaz, Muhammad Amjad 
(2013). Foliar application of some macro and micro nutrients improves tomato growth, flowering and yield. International Journal of Biosciences. 3 (10): 280-287.

Das, RC, Dash, B, Mohapatra, S and Panda, N (1978). Effect of chelating agents on growth, yield and quality of tomato. Orissa Journal of Horticulture. 6 (1-2): 21-30.

Dubey, G.D., Parmar, A.S., Kanwer, H.S., Verma, S.C. and Mehta, D.K. (2013). Effect of micronutrients on plant growth and fruit yield parameters of bell pepper (Capsicum annuum L.) grown under mid hill conditions of Himachal Pradesh. Vegetable Science. 40 (1): 107-108.

Gogoi, S., Das, M. R., Bora, P. and Mazumder, N. (2014). Effect of foliar application of nutrients on fruit and seed production of brinjal (Solanum melongena L.). Indian Journal Assam Agricultural Sci. 2 (1-2): 23 -27.

Kadari, I.A., Dheware, E.M., waghmare, B.D., Mingire, S.S. and Dhawale, K.N. (2015). Influence of micronutrients and biofertilizers on growth, yield and quality attributes of tomato (Lycopersicon esculentum Mill.). Green Farming. 6 (1): 74-76.

Khedr, Z.M.A., Fathy, E.L.E. and Moghazy, A.M. (2004). Effect of some nutrients and growth substances on productivity of eggplant (Solanum melogena var. esculentum) growing under high temperature conditions. Annals of Agricultural Sciences. 42 (2): 583-602.

Kiran, J., Vyakarana, B. S., Raikar, S. D., Ravikumar, G. H. and Deshpande, V. K. (2010). Seed yield and quality of brinjal as influenced by crop nutrition. Indian Journal of Agricultural Research. 44 (1): 1-7.

Meena, D. C., Maji, S., Meena, J. K., Kumawat, Govind, R., Meena, K. R., S.
Kumar and Sodh, K. (2015). Improvement of growth, yield and quality of tomato (Solanum lycopersicum L.) cv. Azad t-6 with foliar application of zinc and boron. International Journal of Bio-resource and Stress Management. 6 (5): 598-601.

Mohsen Kazemi (2013). Effects of Zn, Fe and their combination treatments on the growth and yield of tomato. Bulletin of Environment, Pharmacology and Life Sciences. 3 (1): 109-114.

Naga Sivaiah K., Swain S. K., Sandeep Varma V. and Raju B. (2013). Effect of foliar application of micronutrients on growth parameters in tomato (Lycopersicon esculentum mill.). Journal of Agriculture and Food Sciences. 1 (10): 146-151.

Naidu, A. K., Kushwah, S. S. and Dwivedi, Y. C. (2002). Influence of organic manures, chemical and biofertilizers on growth, yield and economics of brinjal. South Indian Horticulture. 50 (4/6): 370-376.

Natesh, N., Vyakaranahal, B.S., Shekhargouda, M., Deshpande, V.K. (2005). Effect of micronutrient and organics on growth, seed yield and quality of chilli. Karnataka-Journal-ofAgricultural-Sciences. 18 (2): 334-337.

NHB [National Horticulture Board], Horticultural Statistics at a Glance 2015. Available: http://www.nhb.gov.in [2015].

Pandav, A. K., Manoj Kumar Nalla, Aslam, T., Rana, M. K. and Bommesh, J. C. (2016). Effect of foliar application of micronutrients on growth and yield parameters in eggplant cv. HLB 12. Environment \& Ecology. 35 (3): 17451748.

Samira Ibn Maaouia Houimli, Hanen Jdidi, Fatma Boujelben, Mounir Denden (2015). Improvement of tomato (lycopersicon esculentum L.) 
Productivity in calcareous soil by iron foliar application. International Journal of Advanced Research. 3 (9): 11181123

Savitha, H.R., Bidari, B.I., Shashidhara, G.C., Kalyana Murthy, K.N., Poornima, D.S. and Mohan, K.S. (2010). Effect of FeEDTA on growth, yield and quality of red chilli (Capsicum annuum L.). International Journal of Agricultural Sciences. 6 (2): 531-533.

Singh, D.P., Chaubey, T., Singh, B., Mishra, U.C. and Chaubey, P.K. (2014). Balance nutrition in tomato through nutrient management for quality production of fruits. Vegetable Science. 41 (2): 198-201.

Singh, M.V. (2008). Micronutrient Deficiencies in Crops and Soils in India. Micronutrient Deficiencies in Global Crop Production. pp- 93-125.
Suganiya, S. and Kumuthini, Harris, D. (2015). Effect of boron on flower and fruit set and yield of raton brinjal crop. International Journal of Scientific Research and Innovative Technology. 2 (1):135-141.

Tawab, Saleha, Gohar Ayub, Tawab, Faiza, Khan, Owais, Nadia Bostan, Ghazala Ruby, Shawana Ahmad and UmeKalsoom Afridi. (2015). Response of brinjal (Solanum melongena L.) cultivars to zinc levels. ARPN Journal of Agricultural and Biological Science. 10 (5): 172-178.

Yadav, PVS, Abha, Tikkoo and Sharma, NK. (2001). Effect of zinc and boron application on growth, flowering and fruiting of tomato. Haryana Journal of Horticulture Science. 30 (1/2): 105-107.

\section{How to cite this article:}

Uikey, S., M.P. Das, P. Ramgiry, D. Vijayvergiya, P. Ghaday, S.A. Ali and Pradhan, J. 2018. Effect of Zinc, Boron and Iron on Growth and Phenological Characters of Brinjal (Solanum melongena L.). Int.J.Curr.Microbiol.App.Sci. 7(09): 1643-1649.

doi: https://doi.org/10.20546/ijcmas.2018.709.198 